\title{
Short-Term Biochemical Impacts in Cyphoderus javanus Borner (Collembola) as Potential Biomarkers of Fly Ash and Heavy Metal Pollution in Tropical Lateritic Soil
}

\author{
Atreyee Sahana, Vadakepuram Chacko Joy \\ Soil Ecology Laboratory, Department of Zoology (Centre for Advanced Studies), Visva-Bharati University, \\ West Bengal, India \\ Email: Atreyee.Sahana@gmail.com,vcjoy11@visva-bharati.ac.in
}

Received 29 October 2015; accepted 4 January 2016; published 7 January 2016

Copyright (C) 2016 by authors and Scientific Research Publishing Inc.

This work is licensed under the Creative Commons Attribution International License (CC BY). http://creativecommons.org/licenses/by/4.0/

(c) (i)

\section{Abstract}

The detritivorous soil microarthropods are ideal models for environmental health assessment, but only scant information is available on their biomarker potentials against xenobiotics in the tropical edaphic conditions. This microcosm study has estimated short-term biochemical changes with respect to tissue nutrient levels and digestive enzyme activities in a near cosmopolitan Collembola Cyphoderus javanus Borner exposed to coal fly ash amended lateritic cropland soil (5\% and $20 \% \mathrm{w} / \mathrm{w}$ i.e. 50 or $200 \mathrm{t}^{-h^{-1}} \mathrm{a}^{-}$, and cadmium sulphate $(200 \mathrm{mg} / \mathrm{kg}$ soil)/lead acetate (200 $\mathrm{mg} / \mathrm{kg}$ soil) treated sterile river sand. The levels of total tissue carbohydrates, proteins, free amino acids, and lipids decrease within 7 days in the specimens of fly ash $(P<0.001)$ and heavy metals treated sets. The $\alpha$-amylase, cellulase and protease activities are also down regulated by fly ash and heavy metals $(P<0.05)$. It is also observed the enzyme: protein ratios increase in fly ash treated sets and decrease in lead and cadmium treated specimens. Specimens in treated sets accumulate high levels of lead and cadmium within 15 days, which decrease subsequently probably due to elimination through frequent moulting. These short-term biochemical effects in Collembola have applied importance in $C$. javanus, as biomarkers for quick ecotoxicological assessments in the tropical agricultural soils.

\section{Keywords}

Soil Collembola, Tissue Nutrients, Digestive Enzyme Activity, Biomarkers, Ecotoxicology 


\section{Introduction}

The overload of anthropogenic waste materials can produce long-term ecological hazards in soil ecosystems. However, this serious problem is often overlooked, and emphasis is given on the permissible levels of harmful chemicals in the environment to safeguard life and welfare of humans, higher animals and crop plants. On the other hand, accumulation of xenobiotics in soil is deleterious to a wide range of organisms and their ecological functions. Major sources of soil pollution are the overburdens of mines, industrial wastes, urban waste, sewage sludge, inorganic fertilizers and synthetic pesticides. An example is fly ash, a solid waste generated by coal-fired thermal power plants all over the world. In India, fly ash is used in agricultural fields for soil conditioning, nutrient enrichment, and promotion of crop growth and yield. It is a ferro-alumino-silicate mineral occurring as fine particles and is mostly alkaline in reaction. On an average 95\% - 99\% of fly ash is comprised of oxides of silica, aluminium, iron, calcium, potassium, etc, and the remainder is formed of many elements including toxic heavy metals [1]. The concentration of toxic metals like cadmium, zinc, and lead in fly ash can be as high as 130 $\mathrm{mg} \cdot \mathrm{kg}^{-1}, 3500 \mathrm{mg} \cdot \mathrm{kg}^{-1}$, and $5000 \mathrm{mg} \cdot \mathrm{kg}^{-1}$, respectively [2]. Some trace elements are required for the growth of plants and animals, but heavy metals like mercury, cadmium, lead, etc. are not necessary for the growth and development of organisms. Both essential and non-essential heavy metals in high quantities and long exposure periods can be detrimental to soil flora and fauna [3]. Cadmium is an extremely toxic element due to its great solubility in water. Lead is also very toxic to plants and animals at high exposure levels and there is no proven biological need for lead [4].

A wide range of organisms that are heterotropic consumers of preformed organic materials inhabits soil. They regulate the ecological processes through influences on decomposition of dead organic material, nutrient cycling, and formation and maintenance of the soil structure. Interrelated by symbiotic and synergistic interactions, they encompass many life forms that differ in taxonomic categories, trophic relations, life cycle patterns, and niche specializations. Among soil fauna, the microarthropods outnumber others in terms of density and diversity, and groups like Acari and Collembola are potential indicators of soil quality and ecosystem functions [5] [6]. However, they are vulnerable to soil pollution, because majority of species are detritivores and are directly exposed to the toxicants through food. A temperate Collembola, Folsomia candida, Willem has the status of a standard biomarker and is used for testing the toxicity of chemicals on non-target soil animals [7]. The development of biological indicators for soil health analysis has received interest throughout the world, and soil microarthropods are sensitive bioassay models for linking the biomarkers ranging from species to molecular responses to ecological endpoints. However, little information is available on the biochemical ill effects of xenobiotics on soil the tropical ecosystems. Therefore, this microcosm study is designed to estimate the short-term impact of fly ash as a non-specific soil pollutant, and cadmium and lead as specific toxicants on tissue nutrients and digestive enzyme activities in Cyphoderus javanus Borner (Collembola: Insecta), a microarthropod species ecologically relevant to the tropical lateritic soil of India. This near cosmopolitan species is characterised by large population in unpolluted fertile soils, short life cycle, high fecundity, frequent moulting, and year round reproduction in laboratory culture [8].

\section{Materials and Methods}

\subsection{Collection and Rearing of Collembola}

The test species $C$. javanus was collected live from natural field soils by floating on water [9] and mass reared in small polythene vessels $(6.5 \mathrm{~cm}$ diameter, $7.5 \mathrm{~cm}$ height) containing $2 \mathrm{~cm}$ thick layer of moist sandy loam soil. Small quantity of dry baker's yeast was given at weekly intervals as the food source, and the vessels were maintained under controlled temperature $\left(27^{\circ} \mathrm{C} \pm 1^{\circ} \mathrm{C}\right.$ ), moisture (approx $20 \%$ in the soil and $70 \%-80 \% \mathrm{RH}$ inside the vessel), and light dark cycle of 14: $10 \mathrm{~h}$ in a BOD (Biological Oxygen Demand) incubator. The egg laying usually started within three days, and the freshly emerged juveniles were reared separately to obtain specimens of same age group, by transferring the adults into new vessels at regular intervals.

\subsection{Collection of Soil, Sand and Fly Ash}

The sandy loam lateritic soil (0 - $15 \mathrm{~cm}$ topsoil, pH 6.2, EC $0.11 \mathrm{mS} \cdot \mathrm{cm}^{-1}$, WHC $24.2 \%$, OC $0.74 \%$ ) was collected from a local cropland (with no history of chemical contamination), air-dried and passed through $1.0 \mathrm{~mm}$ mesh sieve to remove the fauna, stones and root fragments. The river sand was also collected locally, it was washed 
thoroughly, autoclaved and passed through $1.0 \mathrm{~mm}$ mesh sieve (pH 5.5, EC $0.01 \mathrm{mS} \cdot \mathrm{cm}^{-1}$, WHC $27.5 \%$, OC nil). The source of coal fly ash was the Bakreswar thermal power plant located in the Birbhum district of West Bengal, India ( $23^{\circ} 53^{\prime}$ North Latitude, $87^{\circ} 22^{\prime}$ East Longitude), the ash was collected directly from the dry disposal units (pH 7.9, EC $0.18 \mathrm{mS} \cdot \mathrm{cm}^{-1}$, WHC 51\%, OC 0.38\%).

\subsection{Selection of Heavy Metals}

Cadmium and lead were selected for the study since industrial wastes (coal fly ash, sewage sludge, etc) that are applied in croplands as fertilizer/soil conditioner contain high quantities of these toxic heavy metals [2] [10]. These were applied as cadmium sulphate [ $3 \mathrm{CdSO}_{4} \cdot 8 \mathrm{H}_{2} \mathrm{O}$, Merck Specialities Pvt. Ltd., Mumbai] and lead acetate $\left[\left(\mathrm{CH}_{3} \mathrm{COO}\right)_{2} \mathrm{~Pb} \cdot 3 \mathrm{H}_{2} \mathrm{O}\right.$, Merck Ltd., Mumbai], after dissolving in deionised water (pH 6.5) at $0.1 \%$ concentrations $(\mathrm{w} / \mathrm{v})$.

\subsection{Effect of Fly Ash and Heavy Metals on Life History Parameters in $C_{\text {. javanus }}$}

Microcosm experiments were conducted on the impact of fly ash and heavy metals on growth and reproduction in C. javanus. Total 30 polythene vessels $(5.0 \mathrm{~cm}$ diameter and $5.0 \mathrm{~cm}$ height) were used for the screening, with five replicates each for the treatments. The Control vessels for fly ash treatments contained $10.0 \mathrm{~g}$ soil, and the fly ash treated vessels contained soil amended with fly ash at the rate of 5\% w/w (9.5 g soil $+0.5 \mathrm{~g} \mathrm{FA})$ and $20 \%$ w/w (8.0 g soil + $2.0 \mathrm{~g}$ FA). De-ionised water was used to moist the soil to $50 \%$ WHC, and each vessel contained approximately 10 specimens of 10 days age group (average size $1.8 \mathrm{~mm}$, live weight approximately 0.08 $\mathrm{mg}$ ). Another 15 vessels were used, with five replicates each for the lead and cadmium treatments and the untreated control. Each vessel contained $10 \mathrm{~g}$ river sand moistened with $2 \mathrm{ml}$ of test solution with $0.1 \%$ of respective heavy metal salt solutions or deionised water for control, approximately 10 specimens of 10 days old of $C$. javanus, and few granules of baker's yeast. The vessels were maintained as stated above, and the number of surviving specimens, freshly laid eggs, and exuvia in each replicate was counted at regular 24 hrs intervals for 20 days.

\subsection{Treatments and Experimental Sets}

Similar types of experimental sets were prepared using the similar doses of fly ash and heavy metals (15 vessels for two fly ash doses and their respective control; 15 vessels for heavy metals doses and their respective control) mentioned above. Now, each vessel contained approximately 50 specimens instead of 10 of 10 days old of $C$. javanus. The vessels were kept under the laboratory conditions as stated above for 30 days. Both the experiments were repeated thrice and therefore large numbers of 10-day-old specimens were required.

\subsection{Biochemical Measurements}

After seven days of each experiment, approx 100 specimens were randomly pooled from the replicates of each treatment; they were starved for two $h$ on moist filter paper to empty the gut. The specimens were anaesthetized using ethyl acetate vapour. Whole body homogenate (w/v) of the specimens in phosphate buffer/citrate buffer was centrifuged at $7000 \mathrm{rpm}$ at $4.0^{\circ} \mathrm{C}$ for $15 \mathrm{~min}$ and the supernatant was used for the estimation. A pinch of glass powder was added to facilitate complete homogenization. All the chemicals used were of analytical grade, from the Sigma Chemical Company (USA), Sisco Research Laboratories (India) and E. Merck (India).

\subsection{Tissue Nutrients}

The total tissue carbohydrate content in C. javanus was estimated by hydrolysis of the tissue homogenate (in phosphate buffer $0.02 \mathrm{M}, \mathrm{pH} 7.0$ ) in conc. $\mathrm{H}_{2} \mathrm{SO}_{4}$, which dehydrated glucose in to hydroxymethyl furfural, and formed green colour with anthrone reagent [11]. The O. D. at $620 \mathrm{~nm}$ was measured using a spectrophotometer (Model DU730, Beckman Coulter) against a standard curve for D glucose, and calculated as $\mu$ g carbohydratesmg $^{-1}$ tissue.

The total tissue proteins in $C$. javanus were estimated by reacting the whole body homogenate (phosphate buffer $0.02 \mathrm{M}, \mathrm{pH}$ 7.0) with folin-ciocalteau reagent and alkaline cupric tartrate. The intensity of resultant blue colour was read at $750 \mathrm{~nm}$, using spectrophotometer against a standard curve for bovine serum albumin, and calculated as $\mu \mathrm{g} \cdot$ proteins $\cdot \mathrm{mg}^{-1}$ tissue [12]. 
The total tissue lipid content in $C$. javanus was estimated by digesting the homogenate (in chloroform-methanol mixture) in conc. $\mathrm{H}_{2} \mathrm{SO}_{4}$ [13]. The aliquot formed a pink compound with phosphovanilline. The absorption was measured at $545 \mathrm{~nm}$, using spectrophotometer against a standard curve for pure olive oil, and calculated as $\mu g \cdot$ lipids $\cdot \mathrm{mg}^{-1}$ tissue.

The free amino acid content was quantified by reacting the tissue extract (in citrate buffer $0.2 \mathrm{M}, \mathrm{pH}$ 5.0) with ninhydrin reagent in a boiling water bath, which de-carboxylated $\alpha$-amino acids to yield a blue colour [14]. The intensity was noted in a spectrophotometer at $570 \mathrm{~nm}$, against a standard curve for DL-alanine, and calculated as $\mu \mathrm{g}$ amino acidsmg $^{-1}$ tissue.

\subsection{Digestive Enzyme Activity}

The whole body homogenate of $C$. javanus was used as the enzyme source because of minute size of the animals, and the enzyme activity was expressed as the rate of production of simple units during hydrolysis of a substrate by the corresponding enzyme.

The $\alpha$-amylase activity was estimated by incubating the tissue homogenate (in phosphate buffer $0.02 \mathrm{M}, \mathrm{pH}$ 7.0) with starch at $37^{\circ} \mathrm{C}$ [15]. The resultant simple sugars reacted with hot dinitro salicylic acid reagent and reduced it to nitro amino-salicylic acid. The optical density of this reddish orange solution was read spectrophotometrically at $550 \mathrm{~nm}$ against a standard curve for maltose, and $\alpha$-amylase activity was calculated as $\mu \mathrm{g}$ maltose $\cdot \mathrm{mg}^{-1}$.tissue $\cdot$ hour $^{-1}$.

The cellulase activity in $C$. javanus was measured by incubating the tissue homogenate (in citrate buffer 0.1 $\mathrm{M}$, pH 5.0) with carboxymethyl cellulose at $55^{\circ} \mathrm{C}$ [16]. The simple sugars thus formed reacted with dinitro salicylic acid reagent as described above. The absorbance of resultant yellowish orange solution was measured using spectrophotometer at $540 \mathrm{~nm}$ against a standard curve for D-glucose, and calculated as $\mu g \cdot g l u c o s e \cdot \mathrm{mg}^{-1}$. tissue hour ${ }^{-1}$.

The protease activity was estimated by incubating the tissue extract (in phosphate buffer $(0.1 \mathrm{M}, \mathrm{pH} 7.0)$ with bovine serum albumin at $37^{\circ} \mathrm{C}$ [17]. Trichloro acetic acid was added to stop the hydrolysis, the mixture was centrifuged, and aliquot reacted with ninhydrin in boiling water bath. The optical density was read at $570 \mathrm{~nm}$ in a spectrophotometer against a standard curve for glycine. The protease activity was calculated as $\mu \mathrm{g} \cdot$ glycine $\cdot \mathrm{mg}^{-1} \cdot$ tissue hour $^{-1}$.

\subsection{Heavy Metal Content in Collembola Tissue and Sand/Soil Matrices}

The rates of accumulation of cadmium and lead in C. javanus tissue were compared at 15 and 30 days intervals of the above treatments. The specimens pooled from the replicates of each treatment were starved for two hrs on moist filter paper to empty the gut. The specimens were anaesthetized and digested with aqua regia $(\mathrm{HNO}$ : $\mathrm{HCl}$ $=1: 3 \mathrm{v} / \mathrm{v}$ ) at $70^{\circ} \mathrm{C}$. The digest was diluted with redistilled water, filtered through Whatman No. 42 filter paper, and used for the estimation of cadmium and lead using an Atomic Absorption Spectrophotometer (Model-A Analyst-200, PERKIN-ELMER Make), and expressed as $\mu \mathrm{g} \cdot \mathrm{metalg}^{-1}$ tissue. $^{-}$

The concentrations of cadmium and lead within each matrix were estimated seven days after the treatments. Small portions of soil and sand were taken at random from the metal treated and control vessels. These were air dried, and known weight of respective pooled samples was used to measure the total extractable fraction of heavy metals using analytical grade $\mathrm{HF}-\mathrm{HClO}_{4}$ acids (5:1) [18], and neutral ammonium acetate was used to leach out the exchangeable portions [19]. The solutions were filtered and diluted with redistilled water, and concentrations of cadmium and lead read against reagent blank by an Atomic Absorption Spectrophotometer (Model-AA 240, AGILENT) and expressed as $\mathrm{mg} \cdot \mathrm{kg}^{-1}$ dry matrix.

\subsection{Statistical Analysis}

Statistical analysis and graphical representation of the results were done using the Microsoft Excel, and OriginLab software. The standard error (SE) values of replicates were included for comparing the mean values of different parameters. The experimental data were analyzed using Student's t-test for significant difference between treatments. Data interpretations were made from the percentage differences in treated sets against the control values taken as 100 . The enzyme activities were compared by calculating the ratio between enzyme activity and tissue protein level in control and treated specimens. 


\section{Results}

\subsection{Effect of Fly Ash and Heavy Metals on Moulting and Reproduction in C. javanus}

Table 1 demonstrates important life history parameters namely growth and reproduction in C. javanus. Both parameters were notably reduced within 20 days after treatment. The fecundity of control specimens was 496.71 \pm 67.0 , which decreased to $419.86 \pm 118.27$ in FA $5 \%$ and to $469.14 \pm 117.82$ in FA $20 \%$ treated soil within 20 days. Fecundity was also affected in heavy metal treatments; in control the fecundity was $155.5 \pm 14.86$ which strongly reduced to $72.0 \pm 6.43$ in $\mathrm{Pb}$ treated sets and to $11.0 \pm 3.72 \mathrm{in} \mathrm{Cd}$ treatments within 20 days. Total exuvia production per adult was $31.14 \pm 3.45$ in control soil, which decreased to $27.86 \pm 1.40$ in FA 5\% and to $28.43 \pm 2.28$ in FA $20 \%$ treated soil. Similar reduction of moulting was also observed in heavy metal treatments. Total exuvia production per adult was $31.0 \pm 1.63$ in control, but decreased to $19.5 \pm 4.34$ in $\mathrm{Pb}$ and to $12.5 \pm$ 1.84 in Cd treatments.

\subsection{Effect of Fly Ash and Heavy Metals on Tissue Nutrients}

The tissue carbohydrate content in C. javanus decreased by 51.1\% in FA 5\% and 62.0\% in FA 20\% treated soil (Figure 1) and the differences between untreated control and treated sets were highly significant $(P<0.001)$. The tissue protein level also showed $55.6 \%$ and $56.1 \%$ decline in the specimens of FA 5\% and FA $20 \%$ amended soil, respectively, and significantly differed $(P<0.001)$ with untreated control. Similarly, tissue lipid content in $C$. javanus declined by $20.7 \%$ in FA $5 \%(P<0.05)$ and $66.3 \%$ in FA $20 \%(P<0.001)$ treated specimens. In contrast, tissue amino acid content was not affected by fly ash and decreases were only $0.5 \%$ in FA 5\% and $11.0 \%$ in FA $20 \%$ treated sets.
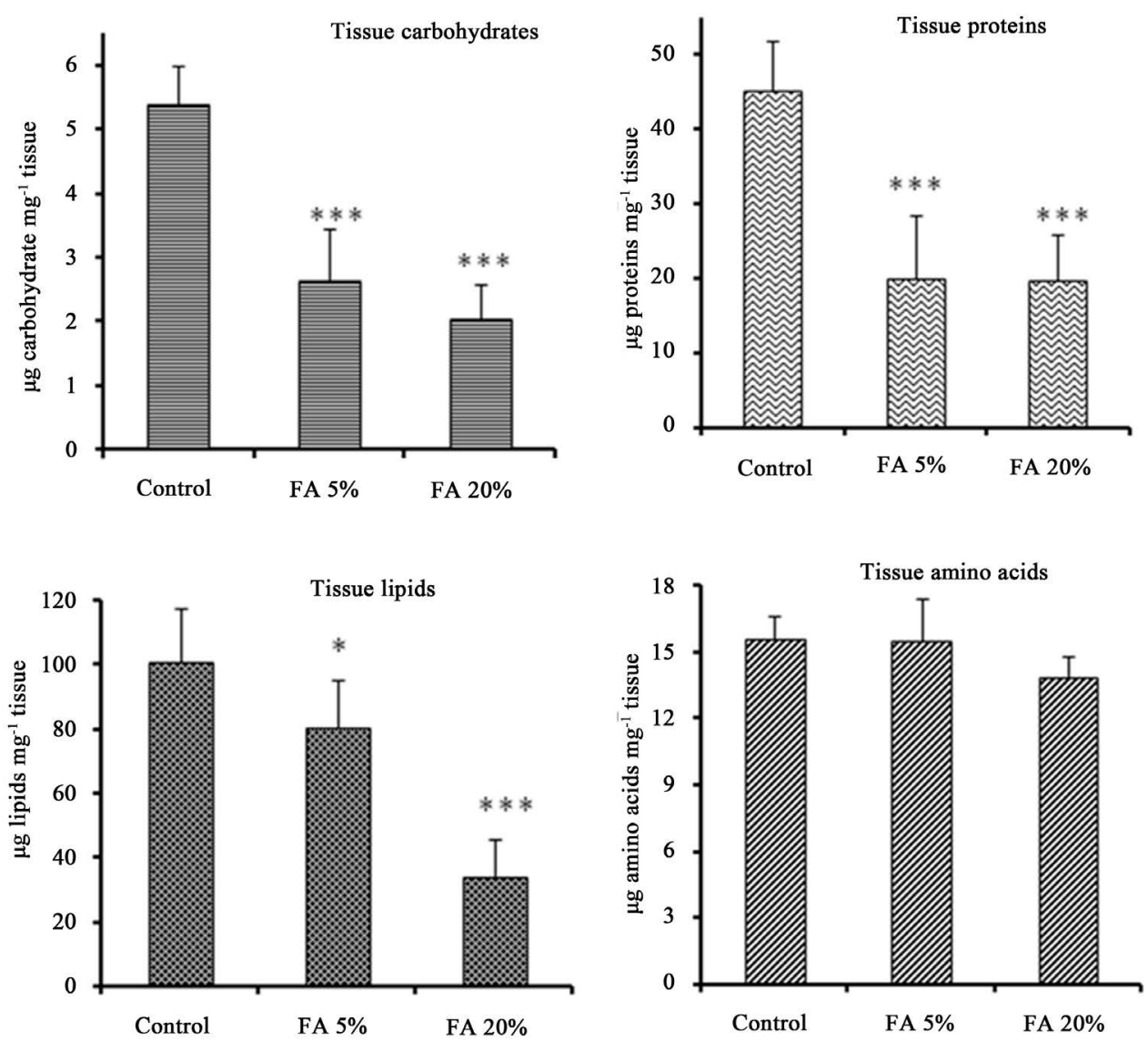

Figure 1. Changes in the tissue nutrient levels (mean $\pm \mathrm{SE}$ ) of $C$. javanus reared in untreated control and coal fly ash $(5 \%$ and $20 \% \mathrm{w} / \mathrm{w})$ treated sandy loam lateritic cropland soil for 7 days. Levels of significance (t-test) $\left(^{*}=P<0.05 ;{ }^{* * *}=P<0.001\right)$. 
Table 1. Comparison of moulting and fecundity in C. javanus exposed to fly ash and heavy metal treatments for 20 days.

\begin{tabular}{cccc}
\hline Treatments & Replications & Moulting (exuvia in 20 days) & Fecundity (eggs in 20 days) \\
\hline Control & 7 & $31.14 \pm 3.45$ & $496.71 \pm 67.0$ \\
FA 5\% & 7 & $27.86 \pm 1.40$ & $419.86 \pm 118.27$ \\
FA 20\% & 7 & $28.43 \pm 2.28$ & $469.14 \pm 117.82$ \\
Control & 7 & $31.0 \pm 1.63$ & $155.5 \pm 14.86$ \\
$\mathrm{~Pb} 200 \mathrm{mg} / \mathrm{kg}$ & 7 & $19.5 \pm 4.34$ & $72.0 \pm 6.43$ \\
$\mathrm{Cd} 200 \mathrm{mg} / \mathrm{kg}$ & 7 & $12.5 \pm 1.84$ & $11.0 \pm 3.72$ \\
\hline
\end{tabular}

Exposure to lead and cadmium also produced ill effects on tissue nutrients in C. javanus (Figure 2). The tissue carbohydrate content decreased within seven days by $15.9 \%$ in $\mathrm{Pb}$ and $23.9 \%$ in $\mathrm{Cd}$ treated river sand, but the differences between control and treated sets were insignificant. The tissue protein content declined by $6.3 \%$ in $\mathrm{Pb}$ and $27.2 \%$ in $\mathrm{Cd}$ treated sets and here also the differences were not significant. Similarly, tissue lipid content decreased insignificantly by $36.6 \%$ in $\mathrm{Pb}$ treated and $25.5 \%$ in $\mathrm{Cd}$ treated specimens. The free amino acid content in tissue declined by $12.3 \%$ in $\mathrm{Pb}$ treated and $41.0 \%$ in Cd treated sets, and significantly differed between control and Cd treated sets $(P<0.01)$.

\subsection{Effect of Fly Ash and Heavy Metals on Digestive Enzyme Activity}

The whole body homogenate of $C$. javanus was rich in $\alpha$-amylase and cellulose activities than protease activity, but the impact of fly ash and heavy metals was evident in all the cases. The amylase activity suffered $21.9 \%$ decline in FA 5\% and 20.3\% decline in FA 20\% treated sets (Figure 3), and the differences between control and treated sets were significant $(P<0.01)$. However, the ratio between amylase activity and tissue proteins increased from 5.32 in control to 9.36 in FA 5\% and 9.65 in FA 20\% treated $C$. javanus. Similarly, cellulase activity was significantly inhibited by $23.0 \%$ in FA $5 \%(P<0.01)$ and $49.5 \%$ in FA $20 \%(P<0.001)$ treated sets. Here also the ratio between cellulase activity and tissue protein content increased from 4.08 in control to 7.09 and 4.70 in FA 5\% and FA 20\% treated specimens, respectively. The protease activity declined $14.1 \%$ in FA 5\% and $20.4 \%$ in FA $20 \%$ treated sets, without any significant difference between control and treated conditions. However, the ratio between protease activity and tissue proteins increased from 0.056 in control specimens to 0.108 in FA 5\% and 0.101 in FA 20\% treated set. A detailed consideration of the results revealed that the higher enzyme: protein ratios were due to low tissue protein content in the specimens of fly ash treated sets.

The ill effects of $\mathrm{Pb}$ and $\mathrm{Cd}$ on digestive enzyme activities in $C$. javanus are depicted in Figure 4. The $\alpha$-amylase activity decreased $47.6 \%$ in $\mathrm{Pb}$ and $60.57 \%$ in Cd treated sets, and the differences between control and treated condition were highly significant $(P<0.001)$. Therefore, the ratio between amylase activity and tissue protein content decreased from 5.14 in control to 2.87 in Pband2.78 in Cd treated animals. Similarly, cellulase activity declined $34.0 \%$ in $\mathrm{Pb}$ and $39.7 \%$ in $\mathrm{Cd}$ treated specimens with highly significant differences between control and treated sets $(P<0.001)$. Therefore, the ratio between cellulase activity and tissue protein content decreased from 3.52 in control to 2.48 in $\mathrm{Pb}$ and 2.92 in Cd treated sets. The protease activity in C. javanus lost $42.5 \%$ in $\mathrm{Pb}$ treated and 33.3\% in Cd treated sets and the differences between control and treated sets were significant $(P<0.05)$. However, the ratio between protease activity and tissue protein content were somewhat similar, and varied from 0.076 in control to 0.052 in $\mathrm{Pb}$ and 0.077 in $\mathrm{Cd}$ treated specimens. In contrast to the fly ash treated sets, here the tissue protein levels did not vary between control and treated specimens, so the enzyme: protein ratios decreased in $\mathrm{Pb}$ and $\mathrm{Cd}$ treated sets.

\subsection{Accumulation of Heavy Metals in Collembola Tissue and Matrices}

Table 2 incorporates the results of AAS study on the accumulation of $\mathrm{Pb}$ and $\mathrm{Cd}$ in the tissues of $C$. javanus, after 15 and 30 days of exposure to the metals and fly ash in microcosm sets. The specimens reared on lead acetate and cadmium sulphate treated river sand accumulated high concentrations of $\mathrm{Pb}$ and $\mathrm{Cd}$ within 15 days, but their levels decreased within 30 days. Similarly, the specimens exposed to fly ash treated soil contained high 

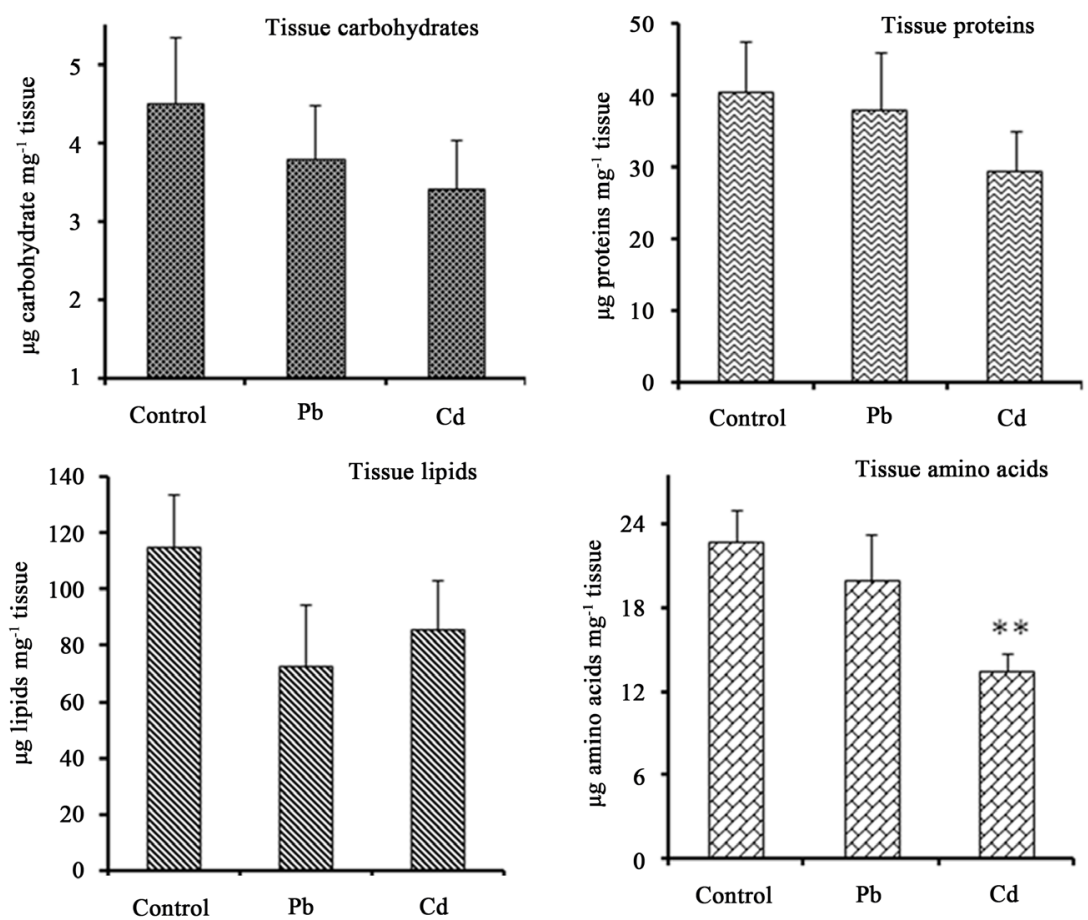

Figure 2. Changes in the tissue nutrient levels (mean $\pm \mathrm{SE}$ ) of $C$. javanus reared in untreated control and lead acetate $(200 \mathrm{mg} / \mathrm{kg})$ and cadmium sulphate $(200 \mathrm{mg} / \mathrm{kg})$ treated sterile river sand for 7 days. Levels of significance (t-test) $\left(^{* *}=P<0.01\right)$.
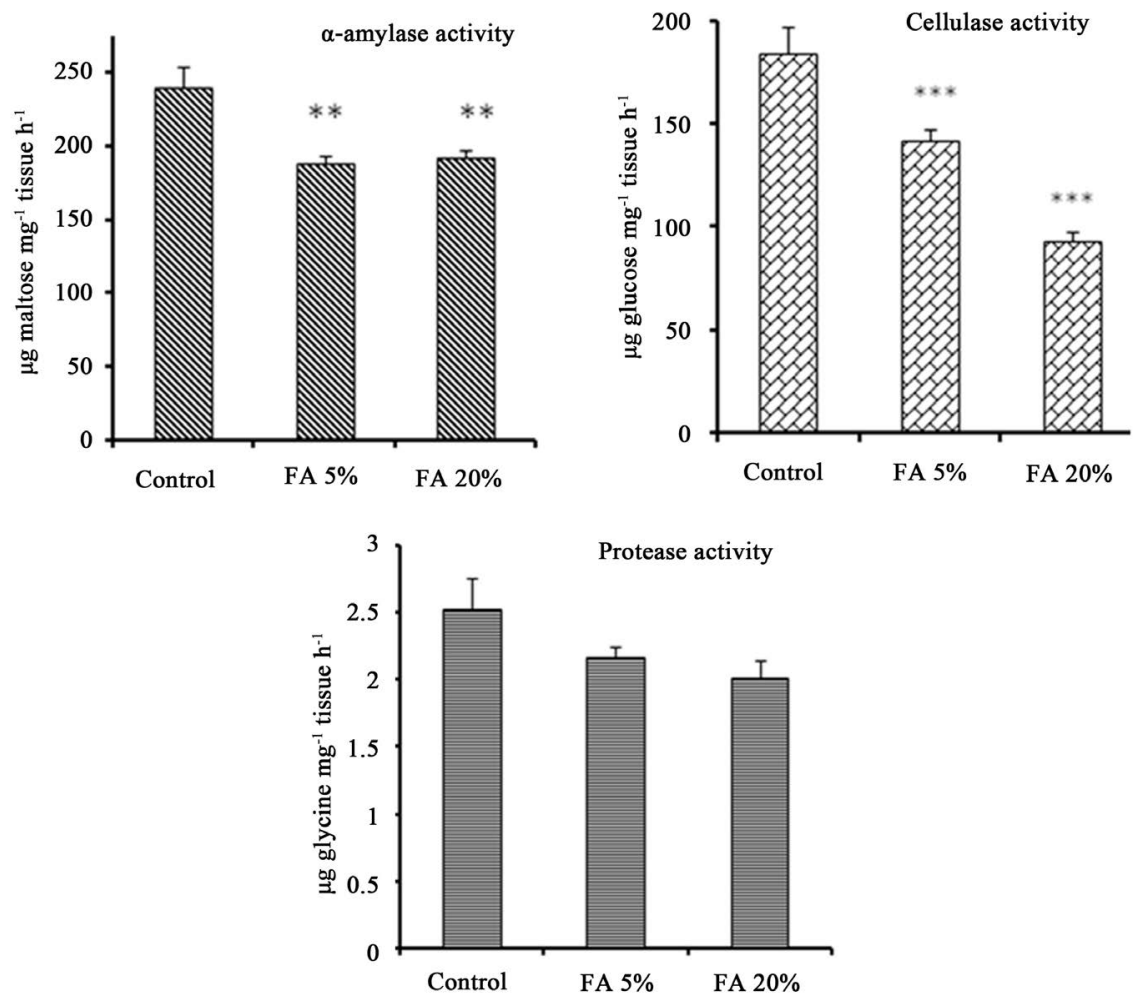

Figure 3. Changes in the digestive enzyme activities (mean $\pm \mathrm{SE}$ ) of $C$. javanus reared in untreated control and coal fly ash (5\% and $20 \% \mathrm{w} / \mathrm{w})$ treated sandy loam lateritic cropland soil for 7 days. Levels of significance (t-test) $\left(^{* *}=P<0.01,{ }^{* * *}=P<0.001\right)$. 

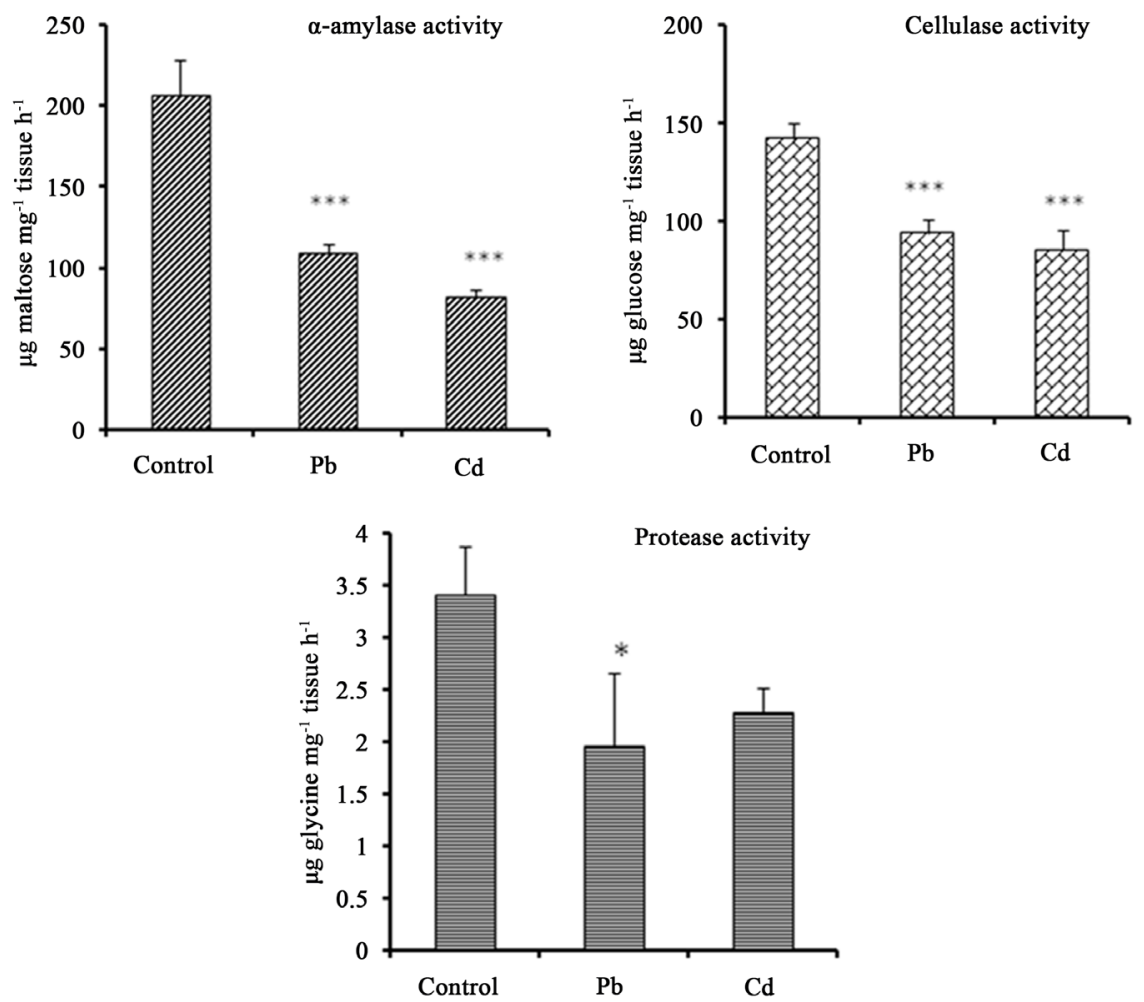

Figure 4. Changes in the digestive enzyme activities (mean $\pm \mathrm{SE}$ ) of $C$. javanus reared in untreated control and lead acetate $(200 \mathrm{mg} / \mathrm{kg})$ and cadmium sulphate $(200 \mathrm{mg} / \mathrm{kg})$ treated sterile river sand for 7 days. Levels of significance (t-test) $\left(^{*}=P<0.05 ;{ }^{* * *}=P<0.001\right)$.

Table 2. Temporal variations in the concentration of lead and cadmium in the whole body tissue extract of C. javanus exposed to the heavy metals and fly ash in microcosms.

\begin{tabular}{|c|c|c|c|c|c|c|}
\hline \multirow{2}{*}{$\begin{array}{l}\text { Rearing } \\
\text { medium }\end{array}$} & \multirow{2}{*}{$\begin{array}{l}\text { Treatments } \\
\text { and doses }\end{array}$} & \multirow{2}{*}{$\begin{array}{l}\text { Interval } \\
\text { in days }\end{array}$} & \multicolumn{2}{|c|}{ Concentration of lead ( $\mu \mathrm{g} / \mathrm{g}$ tissue) } & \multicolumn{2}{|c|}{ Concentration of cadmium ( $\mu \mathrm{g} / \mathrm{g}$ tissue) } \\
\hline & & & Control & Treated & Control & Treated \\
\hline \multirow{4}{*}{$\begin{array}{l}\text { Sterile } \\
\text { river } \\
\text { sand }\end{array}$} & \multirow{2}{*}{$\begin{array}{l}\text { Lead acetate } \\
0.1 \%(\mathrm{w} / \mathrm{v})\end{array}$} & 15 & $67.7 \pm 3.9$ & $247.2 \pm 14.3$ & - & - \\
\hline & & 30 & $39.3 \pm 2.3$ & $150.0 \pm 8.7$ & - & - \\
\hline & \multirow{2}{*}{$\begin{array}{l}\text { Cadmium sulphate } \\
0.1 \%(\mathrm{w} / \mathrm{v})\end{array}$} & 15 & - & - & $47.14 \pm 2.7$ & $159.9 \pm 9.2$ \\
\hline & & 30 & - & - & $23.6 \pm 1.4$ & $124.6 \pm 7.2$ \\
\hline \multirow{4}{*}{$\begin{array}{l}\text { Sandy } \\
\text { loam } \\
\text { soil }\end{array}$} & \multirow{2}{*}{$\begin{array}{l}\text { Fly ash } 5 \%(w / w) \\
(50 \text { tons/ha) }\end{array}$} & 15 & $40.0 \pm 2.3$ & $192.6 \pm 11.1$ & $46.7 \pm 2.7$ & $185.2 \pm 10.7$ \\
\hline & & 30 & $38.0 \pm 2.2$ & $91.2 \pm 5.3$ & $19.2 \pm 1.1$ & $71.9 \pm 4.2$ \\
\hline & \multirow{2}{*}{$\begin{array}{c}\text { Fly ash } 20 \%(\mathrm{w} / \mathrm{w}) \\
\text { (200 tons/ha) }\end{array}$} & 15 & $40.0 \pm 2.3$ & $106.0 \pm 6.1$ & $46.7 \pm 2.7$ & $68.7 \pm 4.0$ \\
\hline & & 30 & $38.0 \pm 2.2$ & $65.6 \pm 3.8$ & $19.2 \pm 1.1$ & $62.0 \pm 3.6$ \\
\hline
\end{tabular}

amounts of $\mathrm{Pb}$ and $\mathrm{Cd}$ within 15 days, which declined within 30 days. However, the tissue metal contents were comparatively low in the specimens confined to FA $20 \%$ treated soil.

Table 3 shows a comparison of the measured concentrations of cadmium and lead within each matrix, estimated seven days after the treatments. Both extractable and exchangeable fractions of cadmium and lead were significantly higher in river sand than in lateritic soil $(P<0.01)$. The acid extraction method yielded approximately $94 \%$ of cadmium and $89 \%$ of lead from the treated river sand, whereas $68 \%$ of cadmium and $66 \%$ of lead were extracted from the treated lateritic soil. However, in both matrices the exchangeable fraction of cadmium ( $46 \%$ in sand and $41 \%$ in soil) was higher than that of lead (19\% in sand and 6\% in soil). 
Table 3. Concentrations of acid extractable and salt exchangeable fractions of cadmium and lead in lateritic soil and river sand samples, and statistical significance of differences between the matrices.

\begin{tabular}{|c|c|c|c|c|c|c|}
\hline \multirow{2}{*}{$\begin{array}{l}\text { Heavy } \\
\text { metals }\end{array}$} & \multirow{2}{*}{$\begin{array}{l}\text { Extraction } \\
\text { methods }\end{array}$} & \multirow{2}{*}{$\begin{array}{l}\text { Experimental } \\
\text { Sets }\end{array}$} & \multicolumn{2}{|c|}{$\begin{array}{l}\text { Concentrations of cadmium } \\
\text { and lead (mg } \mathbf{k g}^{-1} \text { matrix) }\end{array}$} & \multirow{2}{*}{$\begin{array}{l}\text { Level of } \\
\text { significance }\end{array}$} & \multirow{2}{*}{ t-value $P$} \\
\hline & & & Lateritic soil & River sand & & \\
\hline \multirow{4}{*}{ Cadmium } & \multirow{2}{*}{ Total } & Control & $2.76 \pm 0.2$ & $3.95 \pm 0.29$ & 3.265 & $<0.01$ \\
\hline & & Treated & $135.30 \pm 7.8$ & $188.00 \pm 11.6$ & 3.859 & $<0.01$ \\
\hline & \multirow{2}{*}{ Exchangeable } & Control & n.d. & $0.11 \pm 0.01$ & - & - \\
\hline & & Treated & $79.61 \pm 5.57$ & $88.22 \pm 6.88$ & 0.981 & n.s. \\
\hline \multirow{4}{*}{ Lead } & \multirow{2}{*}{ Total } & Control & $46.28 \pm 3.33$ & $52.00 \pm 3.21$ & 1.207 & n.s \\
\hline & & Treated & $131.2 \pm 7.55$ & $177.84 \pm 0.24$ & 3.666 & $<0.01$ \\
\hline & \multirow{2}{*}{ Exchangeable } & Control & n.d. & $0.9 \pm 0.07$ & - & - \\
\hline & & Treated & $12.34 \pm 0.75$ & $40.26 \pm 2.57$ & 10.42 & $<0.001$ \\
\hline
\end{tabular}

Note: Treatments were made @ $200 \mathrm{mg}$ cadmium sulphate or lead acetate $\mathrm{kg}^{-1}$ lateritic soil or river sand, and the concentrations were estimated seven days after the treatments. n.d. = not detected by machine; n.s. = not significant difference.

\section{Discussion}

\subsection{Effect of Fly Ash and Heavy Metals on Life History Parameters in C. javanus}

Microcosm studies showed adverse impact of fly ash and heavy metals on major life history parameters in $C$. javanus. The ill effect of fly ash and heavy metals was prominent on fecundity and moulting. Preliminary studies in this laboratory showed that Collembola could arrest egg laying in polluted soils, and that fly ash could produce strong repellence to several groups of detritivore soil arthropods. Small quantities of fly ash were not detrimental to Onychiurus sp. (Collembola), Trichoniscus sp. (Isopoda), Glomeris sp. (Diplopoda), and Lumbricus sp. (Annelida), but given a choice, they all preferred a clean substrate to a contaminated one. However, rate of reproduction was affected to more than $50 \%$ less [20]. The acute toxicity of different concentrations of cadmium, mercury and lead on the survival and reproduction of Paronychiurus kimi (Lee) (Collembola), and found that $\mathrm{LC}_{50}$ value for cadmium decreased with the exposure time from seven to 28 days, but not or only slightly for mercury and lead [21]. When Collembola Folsomia candida was supplied with $\mathrm{Cd}, \mathrm{Pb}, \mathrm{Cu}$ and $\mathrm{Zn}$ contaminated yeast for seven weeks, the growth rate and reproduction (egg laying time), quantity of food consumed were affected [22]. Therefore, repellency, energy deficiency, physiological stress and direct toxicity in fly ash and heavy metal treated soil could reduce the growth and reproduction in C. javanus. Several scientists have showed that reproduction in Collembola is controlled by the environmental and biological parameters including soil pollutants like pesticides, heavy metals, etc. [7]. This unique parameter in Collembola is an excellent indicator of xenobiotics-induced ill effects in soil.

\subsection{Effect of Fly Ash on Tissue Nutrients and Digestive Enzyme Activities}

There are several reports on the impact of xenobiotics on the demographical and histological parameters in detritivore soil arthropods, but studies on the physiological and biochemical ill effects of soil pollutants are very limited [19] [23]. Present study showed short-term dose-based impact of fly ash on tissue nutrient levels and digestive enzyme activities in $C$. javanus. The higher ratios between enzyme activities and tissue proteins confirmed nutritional deficiency in fly ash contaminated soil. Fly ash has stable negative influence on the physicochemical and microbial properties of cropland soil [24]. The reduced microbial activities in fly ash amended soil are due to high alkalinity, salinity, low organic matter content, and toxicity of trace elements [25]. It is relevant to point out that symbiotic microbes in the gut lumen of Collembola secrete digestive enzymes, which the springtails cannot produce for themselves [26]. It is also known that heavy metals like Cd debilitate the gut microflora of decomposer microarthropods [27] [28]. The screening experiments conducted in this laboratory indicated negligible short term lethal effect of fly ash on several groups of soil arthropods, but there was strong 
repelling effect, and the mortality increased in higher doses and longer durations of exposure. Our findings of significantly low tissue nutrient levels and digestive enzyme activities in $C$. javanus indicated strong physiological and biochemical impact in fly ash treated soil, due to stress factors like repulsion, obstruction, and starvation. Soil microarthropods with short life cycle and high fecundity are sensitive bioassay models, because the bioactivity of toxicants is expressed within a short period of exposure. It appears that cumulative impact of chemicals including toxic metals in fly ash acted as feeding deterrent to Collembola and thus inhibited their energy uptake and related physiological processes.

\subsection{Effects of Lead and Cadmium on Tissue Nutrients and Digestive Enzyme Activity}

The physiological and biochemical ill effects of $\mathrm{Pb}$ and $\mathrm{Cd}$ on $C$. javanus were evident from notable decreases in tissue nutrient levels, but the inhibitions were not as severe as in fly ash treated condition. In contrast, the activities of $\alpha$-amylase, cellulase, and protease decreased significantly in $\mathrm{Pb}$ and $\mathrm{Cd}$ treated conditions. Inhibitory effect of heavy metals on digestive enzyme activities is known in several animals like Asian clam [29], fresh water teleosts [30], and Eastern oyster [31]. It was found that tissue nutrient levels and enzyme activity: protein ratios decreased insignificantly in the treated sets, which suggested that $C$. javanus suffered from direct toxicity in $\mathrm{Pb}$ and Cd treatments. Toxicity depends on the absorption, concentration and persistence of metal species that react with endogenous target molecules, or produce structural and functional changes in the biological system. As already mentioned the toxicity of heavy metals on gut epithelium and on symbiotic microbes in the lumen of gut affected the biochemical processes leading to decreased rate of digestion and assimilation of food [32] [33]. The dose-dependent ultrastructural damage was demonstrated in the midgut epithelial cells in Tetrodontophora bielanensis (Collembola) when fed with $\mathrm{Pb}, \mathrm{Cd}$, or $\mathrm{Zn}$ enriched food [34]. Another study showed that exposure to Cd treated soil produced destruction of mitochondria and microvilli border of cells in the digestive tract of Proisotoma minuta (Collembola) [35]. Some other corroboratory results on the ill effect of heavy metals on food uptake and assimilation, and tissue nutrient profile are in Isopoda Porcellio laevis [36], in Diptera Boettcherisca peregrine [37], and in mosquito Culex pipiens [38]. Most metals disrupt the enzyme functions by binding with sulphur groups in enzymes, and inhibition of enzymes may be due to the making of catalytically active groups or by protein denaturation [39]. Therefore, short-term biochemical effects in Collembola give quick information on the toxicity and persistence of pollutants, since the results are based on actual bioactivity of toxicants. This is in agreement with the statement that recognition of environmental toxicants depends upon the observation on biological damage by the background concentration of toxicants to which the organisms are exposed in the contaminated ecosystem [40].

\subsection{Accumulation of Heavy Metals in Collembola Tissue and Matrices}

Studies on heavy metal toxicity in terrestrial arthropods probably began with the discovery that hepato pancreas of $P$. laevis (Isopoda) collected from the disused mine sites in England contained concentrations of copper which were the highest ever recorded from the soft tissues of any animal [23]. Present results showed that $C$. javanus accumulated high levels of $\mathrm{Pb}$ and $\mathrm{Cd}$ in the body within 15 days of exposure, but the levels decreased within 30 days probably due to excretion through moulting. It is known that Collembola has the capacity to eliminate heavy metals by storing them in gut epithelium and by periodic removal during moulting [41]. High levels of $\mathrm{Pb}$ and $\mathrm{Cd}$ in 5\% fly ash treated $\mathrm{C}$. javanus indicated unabated dietary intake, whereas the low metal contents in $20 \%$ fly ash treated set showed strong repellent property and nutritional deficiency. Metal accumulation and toxicity in soil animals depend on the physiological equipment of the species to regulate its body burden and to deal with excessive exposures [24]. Similarly, bioaccumulation of metals depends on species-specific differences between assimilation and excretion rates. In Orchesella cincta (Collembola) the assimilation efficiency of $\mathrm{Pb}$ and $\mathrm{Cd}$ from a contaminated algal diet was $0.4 \%$ and $8.3 \%$, respectively, but the rate of excretion by moulting was $48 \%$ of $\mathrm{Pb}$ and $30 \%$ of $\mathrm{Cd}$, which led to higher levels of $\mathrm{Cd}$ in tissues [42]. Some scientists observed $\mathrm{Pb}$ concentrations in F. candida linearly increased with increasing $\mathrm{Pb}$ concentrations in the soils [43].

Dissipation of heavy metals in soil depends mostly on the physicochemical properties of the matrix, like organic matter content, clay fraction, mineralogical composition, $\mathrm{pH}$ and more, all of which collectively determine the binding ability of soil to the metals [44]. Present study showed notable differences in the physicochemical qualities between lateritic soil ( $\mathrm{pH} \mathrm{6.2,} \mathrm{EC} 0.11 \mathrm{mS} \cdot \mathrm{cm}^{-1}$, W.H.C. 24.2\%, O.C. 0.74\%) and river sand (pH 5.5, EC $0.01 \mathrm{mS} \cdot \mathrm{cm}^{-1}$, W.H.C. $27.5 \%$, O.C. nil). The soluble plus exchangeable fraction characterises the mobile 
fraction of heavy metals in soil. This fraction also allows an estimation of the bioavailabily of metals [18]. Scientists compared the mobility of heavy metals through water in soil columns and found peak effluent concentrations for cadmium and zinc when compared to low percent of influent concentrations of copper and lead [45]. Literature shows that factors like type of soil, $\mathrm{pH}$, and organic matter content could enhance the metal solubility, plant uptake and leaching to the groundwater. Therefore, the complexation reaction of trace elements in cationic form with inorganic and organic ligands has an important role to play in their toxicity and phytoavailability in soil [46].

\section{Conclusion}

The biomarker potential of biochemical parameters in C. javanus was evident within 7 days of exposure to fly ash and heavy metals. The results indicated that the repellent property of fly ash caused nutritional deficiency, which resulted in the depletion of tissue nutrient levels. In contrast, toxicity of lead and cadmium severely inhibited the digestive enzyme activities. Therefore, the short-term biochemical ill effects in C. javanus were sensitive ecotoxicological indices, and suitable for evaluating the toxicity and bioactivity of pollutants in tropical soils.

\section{Acknowledgements}

The authors are thankful to the University Grants Commission, New Delhi, India, for financial support under the CAS programme of the Department, and AS is grateful for the UGC-BSR Fellowship.

\section{References}

[1] Sadasivan, S. and Negi, B.S. (1991) Chemical Characterization of Fly Ash from Coal Fired Thermal Power Plants in India. Science of Total Environment, 103, 151-158. http://dx.doi.org/10.1016/0048-9697(91)90141-Z

[2] Sharma, S.K. and Kalra, N. (2006) Effect of Fly Ash Incorporation on Soil Properties and Productivity of Crops: A Review. Journal of Scientific and Industrial Research, 65, 383-390. http://nopr.niscair.res.in/bitstream/123456789/4839/1/JSIR\%2065\%285\%29\%20383-390.pdf

[3] Benavides, M.P., Gallego, S.M. and Tomaro, M.L. (2005) Cadmium Toxicity in Plants. Brazilian Journal of Plant Physiology, 17, 21-34. http://dx.doi.org/10.1590/S1677-04202005000100003

[4] Shanker, A.K. (2008) Mode of Action and Toxicity of Trace Elements. In: Prasad, M.N.V., Ed., Trace Elements: Nutritional Benefits, Environmental Contamination, and Health Implication, John Wiley \& Sons Inc., Hoboken, 525-553. http://dx.doi.org/10.1002/9780470370124.ch21

[5] Kuhnelt, W. (1976) Soil Biology with Special Reference to the Animal Kingdom. Faber and Faber, London.

[6] Fountain, M.T. and Hopkin, S.P. (2005) Folsomia candida (Collembola): A “Standard” Soil Arthropod. Annual Review of Entomology, 50, 201-222. http://dx.doi.org/10.1146/annurev.ento.50.071803.130331

[7] Hopkin, S. (1997) Biology of the Springtails (Insecta: Collembola). Oxford University Press, Oxford.

[8] Das, S. and Joy, V.C. (2009) Chemical Quality Impacts of Tropical Forest Tree Leaf Litters on the Growth and Fecundity of Soil Collembola. European Journal of Soil Biology, 45, 448-454. http://dx.doi.org/10.1016/j.ejsobi.2009.09.001

[9] Choi, W.I., Ryoo, M.I. and Kim, J.G. (2002) Biology of Paronychiurus kimi (Collembola: Onychiuridae) under the Influence of Temperature, Humidity and Nutrition. Pedobiologia, 46, 548-557. http://dx.doi.org/10.1078/0031-4056-00159

[10] Obbard, J.P. (2001) Ecotoxicological Assessment of Heavy Metals in Sewage Sludge Amended Soils. Applied Geochemistry, 16, 1405-1411. http://dx.doi.org/10.1016/S0883-2927(01)00042-7

[11] Umbreit, W.N., Burris, R.H. and Stauffer, J.F. (1958) Monometric Techniques. 3rd Edition, Burgess Publishing Company, Minneapolis.

[12] Lowry, O.H., Rosenbrough, N.J., Farr, A.L. and Randal, R.J. (1951) Protein Measurement with Folin Phenol Reagent. The Journal of Biological Chemistry, 193, 265-275. http://www.ncbi.nlm.nih.gov/pubmed/14907713

[13] Floch, J.M.S., Less, M. and Stanely, G.H.S. (1957) A Simple Method for the Isolation and Purification of Total Lipids from Animal Tissue. The Journal of Biological Chemistry, 226, 497-500. http://aufsi.auburn.edu/recommendedmethods/05B01c03a.pdf

[14] Moore, S. and Stein, W.H. (1948) Photometris Ninhydrin Method for Use in the Chromatography of Amino Acids. The Journal of Biological Chemistry, 176, 367-388. http://www.jbc.org/content/176/1/367.full.pdf+html

[15] Bernfeld, P. (1955) Amylase $\alpha$ and $\beta$. In: Colowick, S.P. and Kaplon, N.O., Eds., Methods in Enzymology, Academic 
Press, New York, 149-158.

[16] Sadasivam, S. and Manickam, A. (1992) Biochemical Methods for Agricultural Sciences. Wiley Eastern Ltd., New Delhi.

[17] Anson, M.L. (1938) The Estimation of Pepsin, Trypsin, Papain, and Cathepsin with Haemoglobin. Journal of General Physiology, 22, 79-89. http://dx.doi.org/10.1085/jgp.22.1.79

[18] Bruemmer, G.H., Gerth, J. and Herms, U. (1986) Heavy Metal Species, Mobility and Availability in Soil. Journal of Plant Nutrition and Soil Science, 149, 382-398. http://dx.doi.org/10.1002/jpln.19861490404

[19] Jackson, M.L. (1962) Soil Chemical Analysis. Asia Publishing House, New Delhi.

[20] Eijsackers, H., Lourijsen, N. and Mentink, J. (1983) Effects of Fly Ash on Soil Fauna. In: Lebrun, P.H., Andre, H.M., De Medts, A., Gregoire-Wibo, C. and Wauthy, G., Eds., New Trends in Soil Biology, Proceedings of the 8th International Colloquium of Soil Zoology, Dieu-Brichart, Louvain-La-Neuve, 680-681.

[21] Son, J., Ryoo, M.I., Jung, J. and Cho, K. (2007) Effects of Cadmium, Mercury and Lead on the Survival and Instantaneous Rate of Increase of Paronychiurus kimi (Lee) (Collembola). Applied Soil Ecology, 35, 404-411. http://dx.doi.org/10.1016/j.apsoil.2006.07.002

[22] Fountain, M.T. and Hopkin, S.P. (2001) Continuous Monitoring of Folsomia candida (Insecta: Collembola) in a Metal Exposure Test. Ecotoxicology Environmental Safety, 48, 275-286. http://dx.doi.org/10.1006/eesa.2000.2007

[23] van Straalen, N.M., Butovsky, R.O., Pokarzhevskii, A.D., Zaitsev, A.S. and Verhoef, S.C. (2001) Metal Concentrations in Soil and Invertebrates in the Vicinity of a Metallurgical Factory near Tula (Russia). Pedobiologia, 45, 451-466. http://dx.doi.org/10.1078/0031-4056-00099

[24] Roy, G. and Joy, V.C. (2011) Dose-Related Effect of Fly Ash on Edaphic Properties in Laterite Cropland Soil. Ecotoxicology and Environmental Safety, 74, 769-775. http://dx.doi.org/10.1016/j.ecoenv.2010.10.041

[25] Siddaramappa, R., Wright, R.J., Codling, E.E., Gao, G. and McCarty, G.W. (1994) Evaluation of Coal Combustion Byproducts as Soil Liming Materials: Their Influence on Soil pH and Enzyme Activities. Biology and Fertility of Soils, 17, 167-172. http://link.springer.com/article/10.1007\%2FBF00336317 http://dx.doi.org/10.1007/bf00336317

[26] Borkott, H. and Insam, H. (1990) Symbiosis with Bacteria Enhances the Use of Chitin by the Springtail, Folsomia candida (Collembola). Biology and Fertility of Soils, 9, 126-129. http://dx.doi.org/10.1007/bf00335794 http://link.springer.com/article/10.1007\%2FBF00335794

[27] Drobne, D., Rupnik, M., Lapanje, A., Strus, J. and Janc, M. (2002) Isopod Gut Microflora Parameters as Endpoints in Toxicity Studies. Environmental Toxicology and Chemistry, 21, 604-609. http://dx.doi.org/10.1002/etc.5620210320

[28] Seniczak, A., Ligocka, A., Seniczak, S. and Paluszak, Z. (2009) The Influence of Cadmium on Life-History Parameters and Gut Microflora of Archegozetes longisetosus (Acari: Oribatida) under Laboratory Conditions. Experimental and Applied Acarology, 47, 191-200. http://dx.doi.org/10.1007/s10493-008-9210-6

[29] Barfield, M.L., Farris, J.L. and Black, M.C. (2001) Biomarker and Bioaccumulation Responses of Asian Clams Exposed to Aqueous Cadmium. Journal of Toxicology and Environmental Health Part A, 63, 495-510.

http://www.ncbi.nlm.nih.gov/pubmed/11497331 http://dx.doi.org/10.1080/15287390152410138

[30] Kuz'mina, V.V., Golovanova, I.L. and Kovalenko, E. (2002) Separate and Combined Effects of Cadmium, Temperature, and $\mathrm{pH}$ on Digestive Enzymes in Three Freshwater Teleosts. Bulletin of Environmental Contamination and Toxicology, 69, 302-308. http://link.springer.com/article/10.1007/s00128-002-0061-2

[31] Adeyemi, J.A. and Deaton, L.E. (2012) The Effect of Cadmium Exposure on Digestive Enzymes in the Eastern Oyster Crassostrea virginica. Journal of Shellfish Research, 31, 631-634. http://dx.doi.org/10.2983/035.031.0306

[32] Hopkin, S.P. and Martin, M.H. (1984) Heavy Metals in Woodlice. In: Shutton, S.L. and Holdich, D.M., Eds., The Biology of Terrestrial Isopod, Proceedings of the Symposium of the Zoological Society of London Number 53, Clarendon Press, Oxford, 143-166.

[33] Lapanje, A., Rupnik, M. and Drobne, D. (2007) Gut Bacterial Community Structure (Porcellio scaber, isopoda, crustacea) as a Measure of Community Level Response to Long-Term and Short-Term Metal Pollution. Environmental Toxicology and Chemistry, 26, 755-763. http://dx.doi.org/10.1897/06-099R.1

[34] Pawert, M., Triebskorn, R., Gräff, S., Berkus, M., Schulz, J. and Köhler, H.R. (1996) Cellular Alterations in Collembolan Midgut Cells as a Marker of Heavy Metal Exposure: Ultrastructure and Intracellular Metal Distribution. Science of Total Environment, 181, 187-200. http://dx.doi.org/10.1016/0048-9697(95)05009-4

[35] Nursita, A.I., Singh, B. and Lees, E. (2009) Cadmium Bioaccumulation in Proisotoma minuta in Relation to Bioavailability in Soils. Ecotoxicology and Environmental Safety, 72, 1767-1773.

http://dx.doi.org/10.1016/j.ecoenv.2009.05.009 
[36] Joy, S., Maity, S.K. and Joy, V.C. (1998) Digestive Enzymes in Porcellio laevis (Isopoda: Crustacea) as Indicator of Heavy Metal Toxicity in Soil. In: Aditya, A.K. and Haldar, P., Eds., Biodiversity and Environment, Proceedings of the National Seminar on Environmental Biology, Daya Publishing House, Delhi, 79-86.

[37] Wu, G.X., Ye, G.Y., Hu, C. and Cheng, J.A. (1996) Accumulation of Cadmium and Its Effects on Growth, Development and Hemolymph Biochemical Compositions in Boettcherisca peregrina Larvae (Diptera: Sarcophagidae). Insect Science, 13, 31-39. http://dx.doi.org/10.1111/j.1744-7917.2006.00065.x

[38] El-Sheikh, T.M.Y., Fouda, M.A., Hassan, M.I., Abd-Elghaphar, A.-E. A. and Hasaballah, A.I. (2010) Toxicological Effects of Some Heavy Metal Ions on Culex pipiens L. (Diptera: Culicidae). Egyptian Academic Journal of Biological Science, 2, 63-76. http://toxicology.eajbs.eg.net/pdf/vol2-n1/9.pdf

[39] Das, P., Samantaray, S. and Rout, G.R. (1997) Studies on Cadmium Toxicity in Plants: A Review. Environmental Pollution, 98, 29-36. http://dx.doi.org/10.1016/S0269-7491(97)00110-3

[40] Alikhan, M.A. (1997) A Comparative Study on the Fecundity and Juvenile Survival in Pocellio spinicornis (Porcellionidae: Isopoda) from a Nickel-Copper Contaminated and Uncontrolled Site in Northeastern Ontario, Canada. In: Hassall, M., Hornung, E. and Warburg, M.R., Eds., Proceedings of 4th Symposium on the Biology of Terrestrial Isopods, Laser Pages Publishing, Haifa, 15.

[41] Joosse, E.N.G. and Buker, J.B. (1979) Uptake and Excretion of Lead by Litter Dwelling Collembola. Environmental Pollution, 18, 235-240. http://dx.doi.org/10.1016/0013-9327(79)90105-8

[42] van Straalen, N.M., Burghouts, T.B.A., Doornhof, M.J., Groot, G.M., Janssen, M.P.M., Joosse, E.N.G., van Meerendonk, J.H., Theeuwen, J.P.J.J., Verhoef, H.A. and Zoomer, H.R. (1987) Efficiency of Lead and Cadmium Excretion in Populations of Orchesella cincta (Collembola) from Various Contaminated Forest Soils. Journal of Applied Ecology, 24, 953-968. http://www.jstor.org/discover/2403992?sid=21105662894663\&uid=2129\&uid=2\&uid=70\&uid=4 http://dx.doi.org/10.2307/2403992

[43] Luo, W., Verweij, R.A. and van Gestel, C.A.M. (2014) Assessment of the Bioavailability and Toxicity of Lead Polluted Soils Using a Combination of Chemical Approaches and Bioassays with the Collembolan Folsomia candida. Journal of Hazardous Materials, 280, 524-530. http://dx.doi.org/10.1016/j.jhazmat.2014.08.044

[44] Dube, A., Zbytniewski, R., Kowalkowski, T., Cukrowska, E. and Buszewski, B. (2001) Adsorption and Migration of Heavy Metals in Soil. Polish Journal of Environmental Studies, 10, 1-10. http://math.tongji.edu.cn/model/docs/dube.pdf

[45] Camobreco, V.J., Richards, B.K., Steenhuis, T.S., Peverly, J.H. and McBride, M.B. (1996) Movement of Heavy Metals through Undisturbed and Homogenized Soil Columns. Soil Science, 161, 740-750. http://soilandwater.bee.cornell.edu/publications/CamabrecoSS96.pdf http://dx.doi.org/10.1097/00010694-199611000-00003

[46] Violante, A., Cozzolino, V., Perelomov, L., Caporale, A.G. and Pigna, M. (2010) Mobility and Bioavailability of Heavy Metals and Metalloids in Soil Environments. Journal of Soil Science and Plant Nutrition, 10, 268-292. http://dx.doi.org/10.4067/S0718-95162010000100005 